$$
\begin{aligned}
& \text { 21. ल स C } \\
& \text { decords }
\end{aligned}
$$

ORIGINAL LOG BOOK OF THE "FISH HAWK"

UNITED STAPES FISH COMISSION

STATION NUMBEES

Numbers 1078 to 1121 
Sos

A , stations 1078 th 
$10 \geq 8$

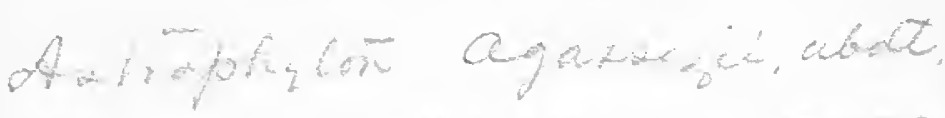
Aleypunin Carnesum, reare,

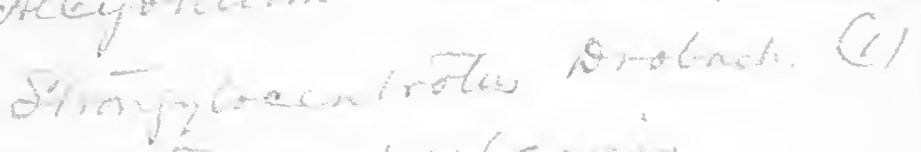
Azliñai betgarts Geñabuzer encidalus

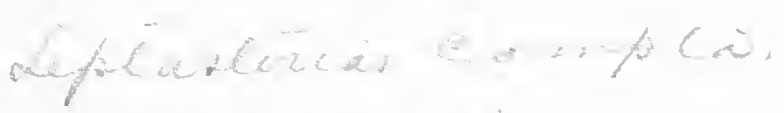
Rowaio Aratcié Gpticha Zotandica

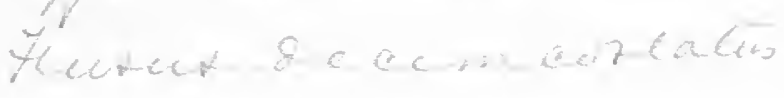

ofte bearaing Thagneté,

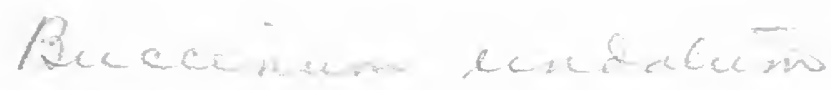
Ecrpaprew

Racedicat

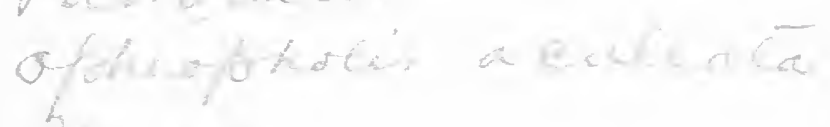

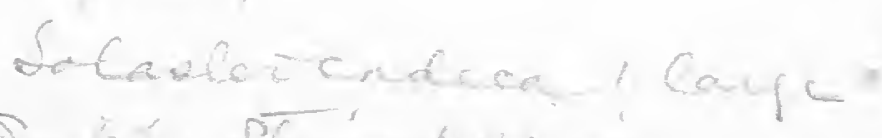

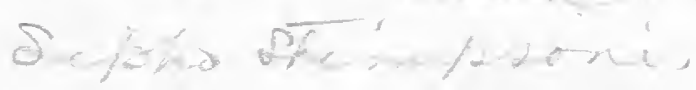




\section{TEMPERATURE RECORD.}

Instrument used,

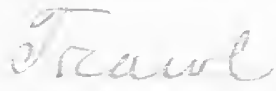

Current number of observation, $/ C .8$.

Date, $\mathrm{Z}_{2}, \mathrm{f}, \mathrm{S} 82$

Locality,
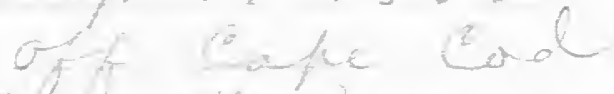

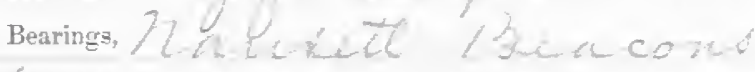

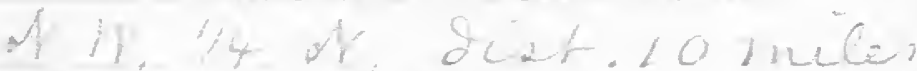

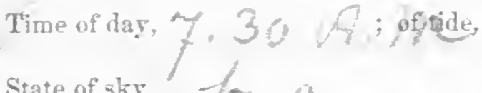

State of sky, to,

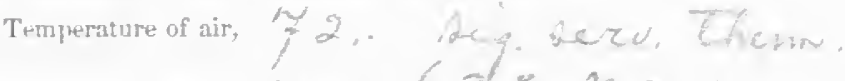

“ surface of water. $\quad 63=97.3=47996$

" at depth of $5^{-}$fathoms. $566^{l} 5 / 0 / 40^{\circ}$

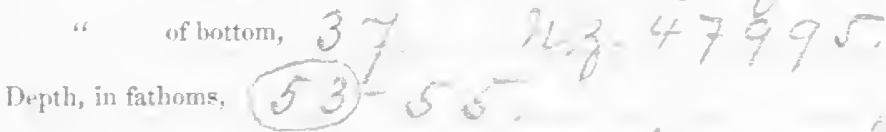

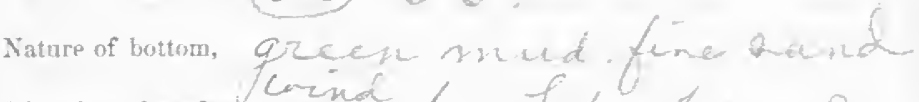

Direction of swface chrseut,

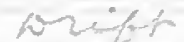

Fonetor-anface current, it by,

Direction of bottem eurrent;

Force of bottom current,

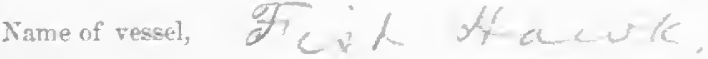

To what service attached, $\quad l t, \delta, y t<$.

Name and rank of commanding officer,

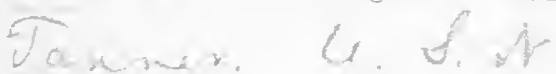

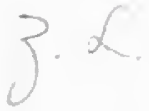

Nane and position of ohserror,

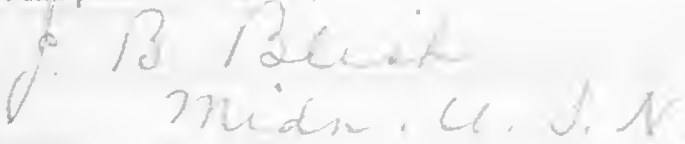


$107 \%$

REMARKS.

\&

opprua Qucarbeia

inacoma rabulora

Tercbralutería

Lacearawa arecía

geariner Réiqua.

ofnoma araceata

Natarcé lens inabue

lictieuna callosa. 


\section{TEMPERATURE RECORD.}

Instrument used,

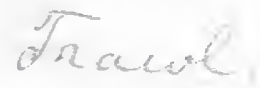

Current number of observation, $\quad$ o $7=$

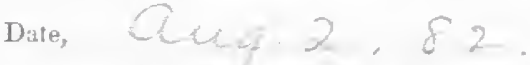

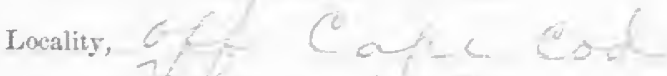

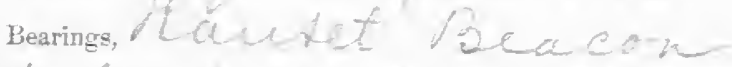

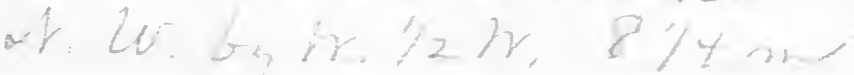

Time of day, $F=456$ - of tikle,

State of sky, \&o $k^{3}$

Temperature of air, 69 .

" surface of water, 63.3

$\therefore \quad$ at depth of 5 fathoms, $56, \sqrt{6}$

" of bottom, $\mathcal{2}$

Depth, in fathoms, $y^{2} 9^{\prime} 61 / 2$

Nature of bottom, $<1<C$

Direction of surface current,

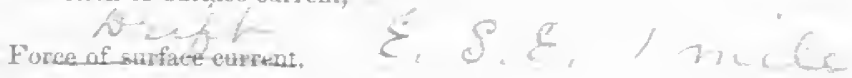

Direction of bottom carrent,

Force of butom current,

Name of ressel,

To what service attached.

Name and rank of commanding wficer,

Name and position of olsserser, 
1080

REMARKS.

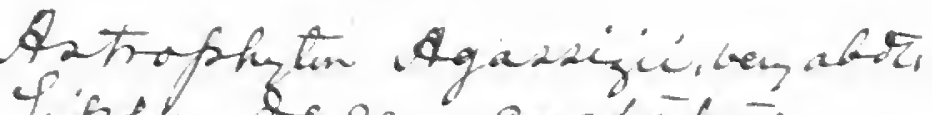

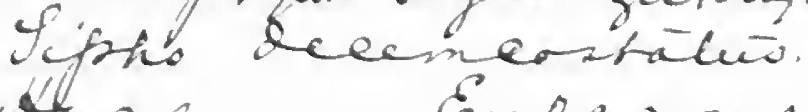

Has. Eupagurses.

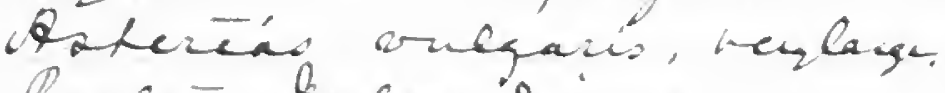
Recen \&zcandiens.

fracedata horacgeia

$$
\text { arclecá }
$$

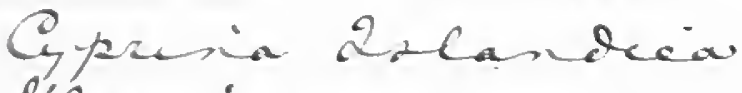
Hecmisi.

cactain bicandicam.

fiph ateinptons

hacana lakakama.

Aucenium kndakam

Qparakar accibencáb.

Anomia aceccalá

Aippazlezid phaguara

Leticuiar Calcosas

rabacera Frebrac.

Cleñubixens cuiphano

Chaluia 


\section{TEMPERATURE RECORD.}

Instrument used,

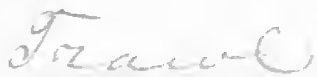

Current number of obserration,

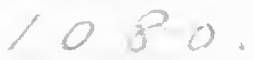

Date,

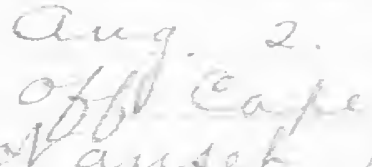

$18 \& 2$

Locality,

Bearings, al ace $A \hat{b} h$

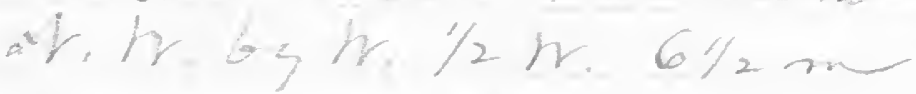

Time of das, 9,60 boftide 6 .

State of sky, fo, c,

T-mperature of air, $\quad 6 \%$

s surface of water, 6,5

a at depth of 5 fathoms, 56 .

" of bottom, $3 \div$

Depth, in fathoms, $\quad 53=53$

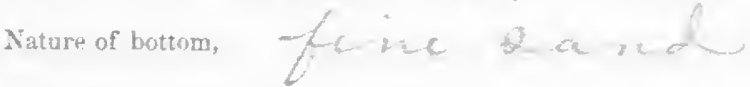

Direction of surface current,

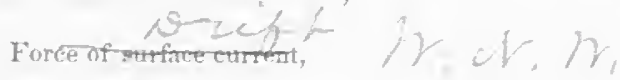

Direction of bottom current,

Force of bottom current,

Name of ressel,

To what service attached,

Name and rank of eommanding officer,

Name and position of ohserver, 
1081.

REMARKS.

Carbuin Recanhean gecimers Reciqua dejpi qacandican Sfleinca o ancí.

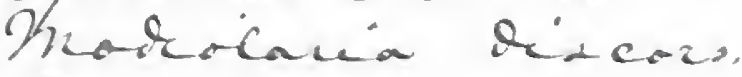
Pecce: 2 Leandicus taceciana arctéa Buceunin andalumin.

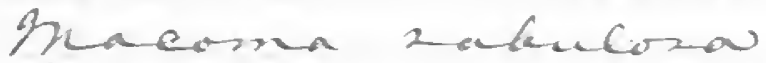
Tipho ececmetrakew. 


\section{TEMPERATURE RECORD.}

Instrument used,

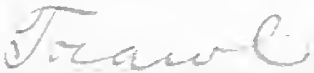

Current number of observation, $/ 0 \mathrm{~S}$,

Date,

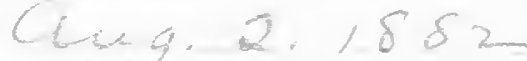

Locality,

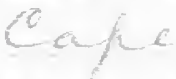

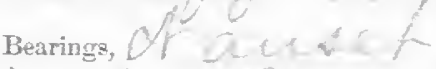

/

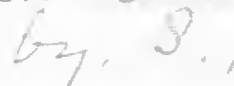

aj 12 macks

Time of day, $/ 0, \sqrt{ } 0$; of tide,, $\mathrm{n}$

State of sky,

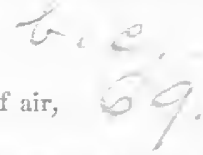

Temperature of air, if

"surface of water, " at depth of $/ 4$ fathons, 40 .

" of bottom

Depth, in fathoms, 32

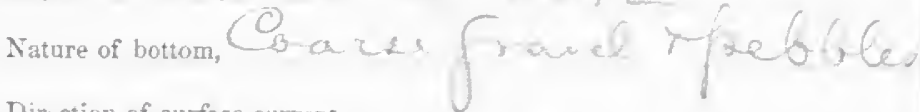

Direction of surface current,

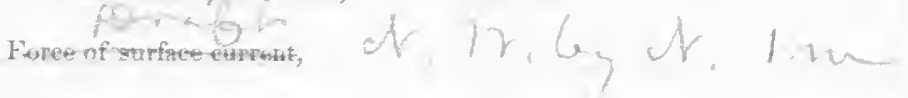

Direction of bottom current,

Force of buttom current,

Name of ressel,

To what service attached,

Name and rank of commanding officer,

Name and position of ohserser, 
108 요,

REMARKS. Meserincuín secigua Hobrica madiotus 


\section{TEMPERATURE RECORD.}

Instrument used,

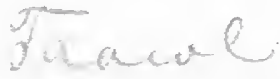

Current number of ubserration, $\quad(082$

Dute, $Q 20,82$

Locality,

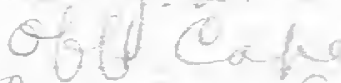

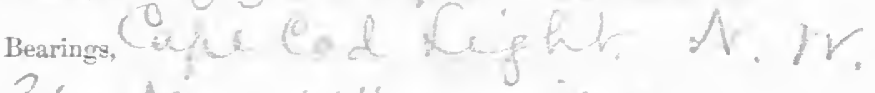

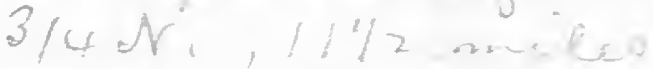

Time of day, $/ 1+\frac{1}{i} S$ G tofitide,

State of sky, $6=0$.

Temperature of air,

$\therefore \quad$ surface of water, $5 \div$

* at depth of fathoms,

" of bottom, 40 .

Depth, in fathoms, $2=-28$.

Nature of bottom,

Direction of surface current,

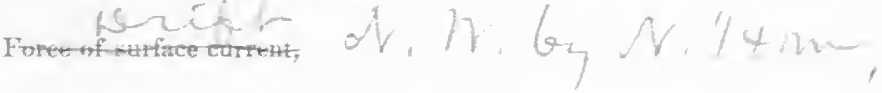

Direction of bottom curreut,

Force of bottom current,

Name of ressel,

To what sersice attached,

Name and rank of commanding officer,

Name and position of ohserser, 
1083,

REMARKS.

Oppraia Iscandeca

Apparkado a ciber Gab

gacmicus direqua Pcpho wheriphon le fula caccas?

inpagums

tocazlar exdecas. 
TEMPERATURE RECORD.

Instrument used,

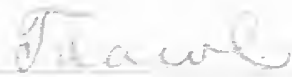

Current number of ulserration, $\quad(083$,

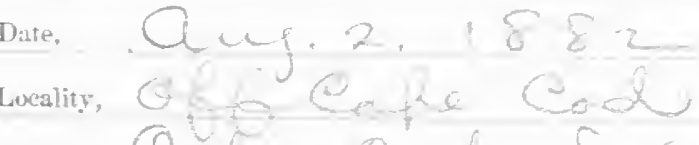

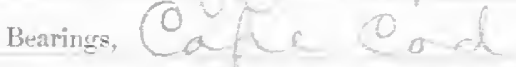

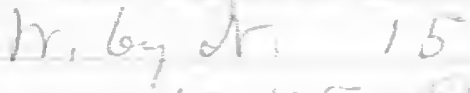

an jer

Time of day, $f-y, y \mathfrak{S}^{-}$; of tire,

State of sky, ti e

Temperature of air;

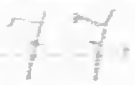

"s surface of water, $6 \ll$

$\therefore$ at depth of $/ 0$ fathoms, 42

“ of bottom, 3 है

Depth, in fathoms, $80-83 / / 2$

Nature of bottom,

Direction of surface com rent,

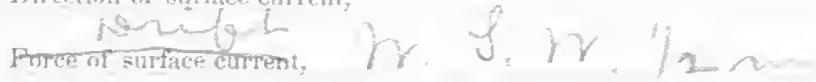

Direction of bottom current,

Force of bottom current,

Name of vessel,

To what service attached,

Name and rank of commanding officer,

Name and position of observer,

sealant 
1084

REMARKS. Pencacta from dora. Weylaye.

Pandacas Coptaceron?

\& $\alpha_{2}$ as.

Reccer 2acaridas.

apcinca on.aci:

- Hycuriono Recisua chani 216andicas Diph 2h-12zan: peceí Lenuederatas leppagumo

zacanus porcaks?

formin aculcala Rocarce cueca.

Chtcaín Rucgavio.

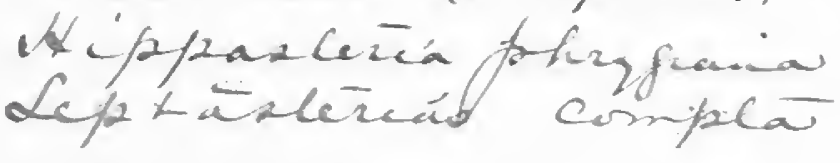




\section{TEMPERATURE RECORD.}

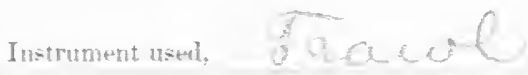

Current number of obsersation, $\quad l Q S 4$

Date,

Lotalit5,

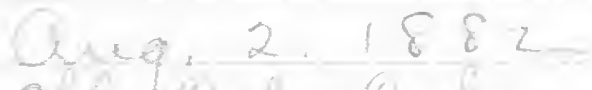

Bearings.
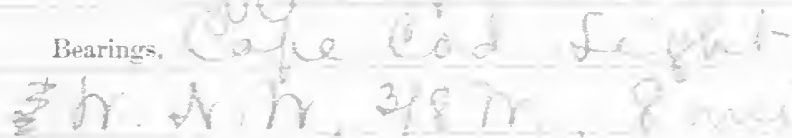

Time of day, को. 20 fortite...

State of sky, $b . c$.

Temperature of air, of $ई$.

"surface of water, 602.

. at depth of $/ 0$ fitlomik, 43,5

$\therefore$ of bottum, 38 ,

Depth, in fathoms,

Nature of botton,

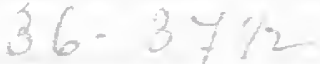

Direction of surface current,

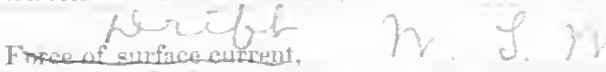

Direction of bottum current,

Force of bottom current,

Name of ressel,

To what service attached,

Name and rank of commanding officer,

Name and position of observer, 
1085

REMARKS.

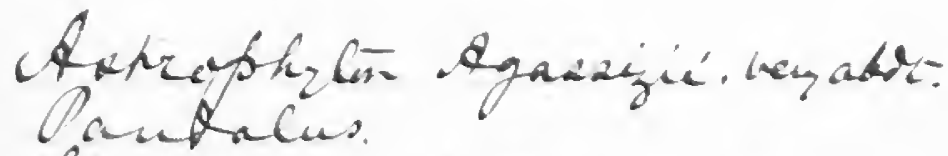

Howng, coecutration vorack.

Regrinain carnawn Reupationo

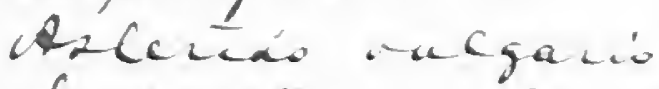
Ceplazlazía Conpta.

Oribecla basiguniabala

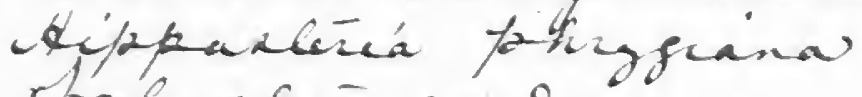
cocarcaz cuecca Plezcia dicandeca cartuin Recandecan

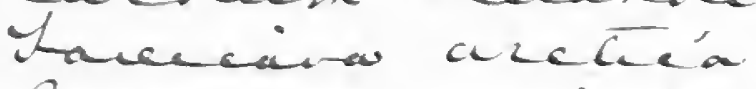
2acecmim, antelam fepk Rtimpani

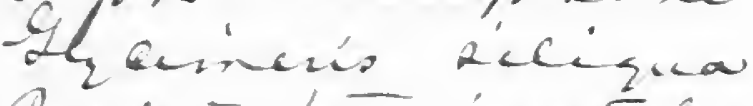

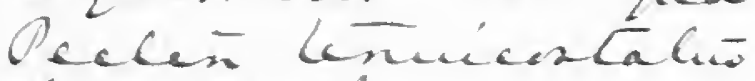
efptaicé less, opusica aracio. ppparkarb recidenbat. Peción Ecalone in 


\section{TEMPERATURE RECORD.}

Instrument used,

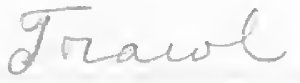

Cnrrent number of obsarvation, $/ 085$,

Date, Guen, 3, 1882

Loeality,

Bearings. Fa es

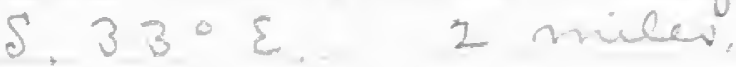

Time uf lay, 6,15 arminti:

State of sky, t, c,

Tomperature of air,

$6 \%$

as surface of water, 64,

at depth of 5 fathens, $61,10 / 61+43$,

.. of bottinin, 39 .

Depth, in fathom: $33-34 / 2$

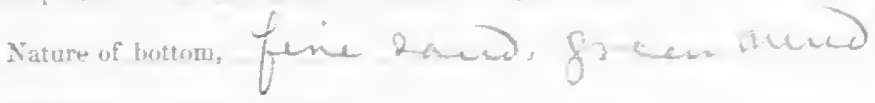

Direction of surface current,

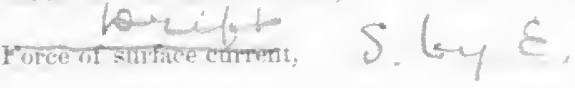

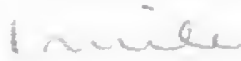

Direction of bettem current,

Force of bottom current,

Name of ressel,

To what service attached,

Name and rank of commanding officer,

Name and position of observer, 
1086

REMARKS.

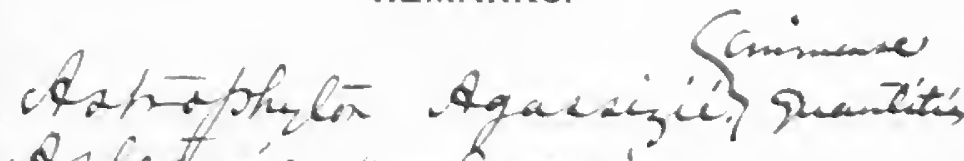
4alctuá: mesan:

Aanialus Reptodiños.

Chropotolí aculeata deptarlazías Somplat Rolarker endecal

Orciazclar Rangunintenta

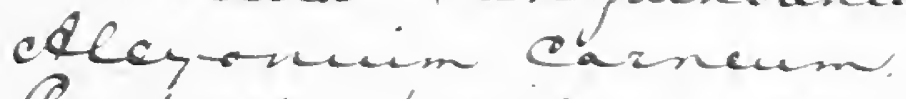

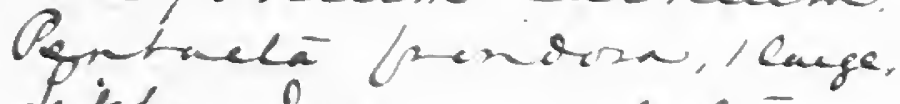
dopted decescuscalus hatiolas maciola Cactrion Acecandecam oterica macio

gezina Recandica Peclen I calarifcino Margarica abrenro Dencesina aickéa Alunelunclea noachanía Reluliñó habiotoidea 
TEMPERATURE RECORD.

Instrument used,

drawer

Current number of observation, $/ 0.86$,

Date, Aug, 3, 7882

Locality, of bearings,

s. $20^{\circ} \mathrm{h}, \quad 23 / 4$ miles

Time of day.
State of sky.

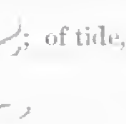

Temperature of air, $\frac{1}{1}$,

surface of water, 64

$\therefore \quad$ at depth of 10 fathoms: 44.

" of bottom. $391 / 2$

Depth, in fathoms.

Nature of bottom,

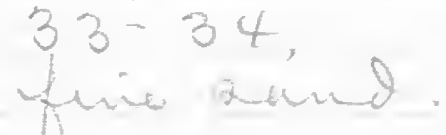

Direction of surface current,

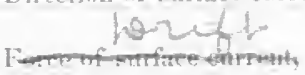

$\delta$.

2

cod

Left

Direction of bottom current,

Force of bottom current,

Name of vessel,

To what service attached,

Name and rank of commanding officer,

Name and position of observer, 
1 a 87

REMARKS. Acjoparletrá fouzgaina Dandalus

Reloena gresias

11 multicosmós

Hydracs.

Rzyozara.

Gubrella bangurdenta Rasze: bath decementatuo

g/vizuca a in aciö.

gpunia Occlastéa eclañ Leñuicalatus depcha caeca. Sackcana asctéá 
TEMPERATURE RECORD.

Instrument used,

Trawl

Current number of ob bereration, 1087

Date, Aug. 3. 1882

Locality, off Cafe Cad S. P, ty, 7 miles

Time of day. 8,30 fustier,

State of sky, le. e.

Temperature of ail, 84 .

" surface of water, 62,5

." at depth of 5 fathom is, $46,10 \mathrm{fun} 41$.

. If bottom, 39.

Dep ph, in fathoms, $42-44$,

Nature of bottom, Grey a and

Direction of surface current,

sincitib

h. \&. or

$1 / 2$

Direction of bottom current,

Force of bottom current,

Name of vessel,

To what service attached,

Name and rank of commanding officer,

Name and position of observer, 
$/ o f f$

REMARKS.

Apprakaci occidentale Qcpho decemerslakin.

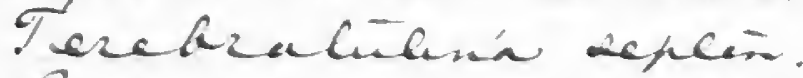
Ruccumin andulan Car fun deckandean Acchir

Lencuicastater

Hounlé less.

Q tounia Icecandeca Axcecina karbegicer Qnomid aenceala Lumatín

Maléa Clausa

inacoma sabulozas ho-rolavia avicars. 3 Cuphacanas. Rucliécina hatozas Bolocua gruesio.

multiennó.

Aandibus taracab ctiparasténá

Oalaseis. Rosamia.

Crabella Ranguinalenta ofunge. ophiopholís a enberta

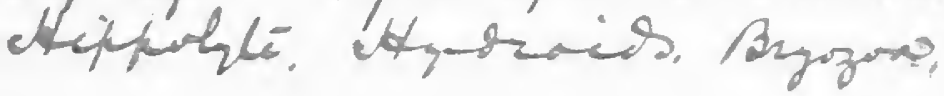




\section{TEMPERATURE RECORD.}

Instrument used,

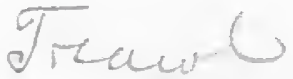

Current number of observation,

Date,

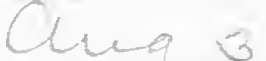

1088

Locality,

Bearings,

s. h, 3/4 hr.

Time of das, 9,50 ; of tidu,

r f o 2

State of sky, 0,

Temperature of air, 82,5

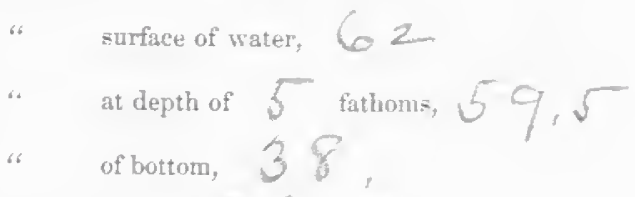

Deptb, in fathoms, $86-90$

Nature of bottom,

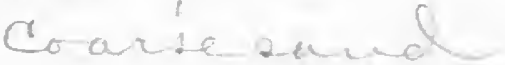

Direction of surface current,

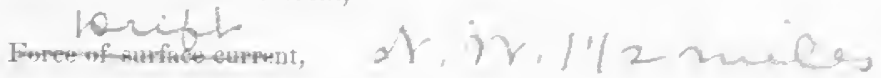

Direction of bottom current,

Force of bothom current,

Name of ressel,

To what service attached,

Name and rank of eommanding officer,

Name and position of observer, 
REMARKS. 
TEMPERATURE RECORD.

Instrument used,

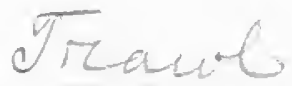

Current number of observation, / 68

Date,

Locality,

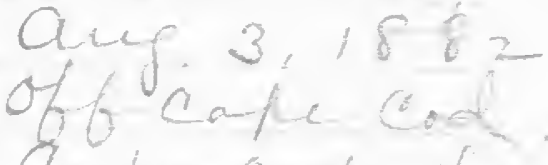

Bearings,

S. Tr.

$\cos d$

3

Lift

14 merles

Time of day, $1,1,10$; of 6 id er 20

State of sky,

Gee,

Temperature of air,

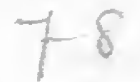

$\therefore$ surface of water, 63.

“ at depth of fathoms,

" of bottom, 38,5

Depth, in fathoms, $106-110$.

Nature of bottom,

Direction of surface current,

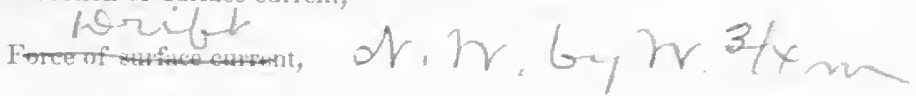

Direction of bottom current,

Force of bottom current,

Name of vessel,

To what service attached,

Name aud rask of commanding officer,

Name and position of olnertor,<smiles></smiles> 
1090.

REMARKS.

Apporkai occenciats Lavecama lazageia Qubance lens.

Hatera Thracifazm.

Recen - Acandea

inga lanseala Lifhe paygimaer

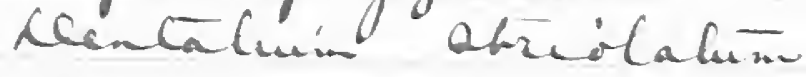
accidencté.

Laceri appatieca Neacra aratéa Cachnion finincalun Lesa Lenuizaceala hacmen th. 


\section{TEMPERATURE RECORD.}

Instrument ased.

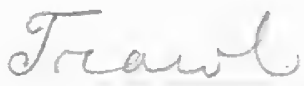

Current number of observation, $/ 090$

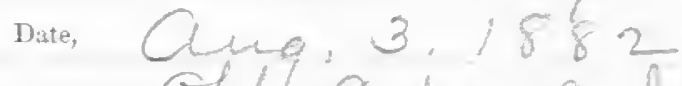

Locality,

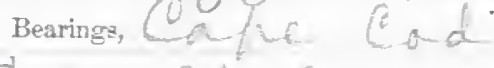

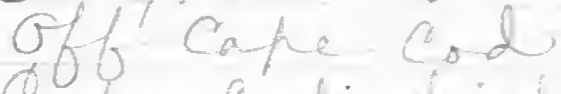

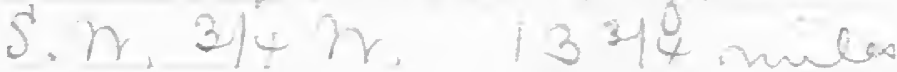

Time of day, 1 1, 50 ; of tidectu

State of sky, $\quad \ell, e$

Temperature of air,

" surface of water, $\quad 62$

" at depth of 5 fathoms, $56,10+2$

" of bottom, 38,5

Depth, in fathoms, $166=110$

Nature of bottom,

Direction of surface current,
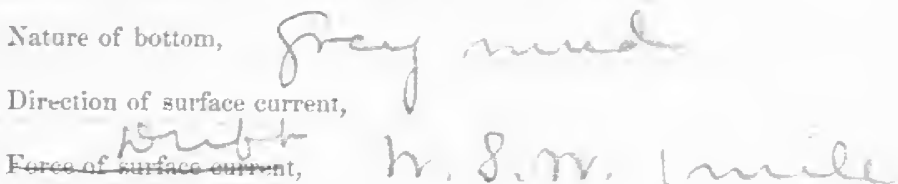

Direction of bottom carrent,

Force of bottom current,

Name of ressel,

To what serrice attacherl,

Name aul rank of cummanding officer,

Name and position of obsarver, 
1091.

REMARKS.

Archarlet Aneccianus, vey abs? Pascolates. 


\section{TEMPERATURE RECORD.}

Instrument used,

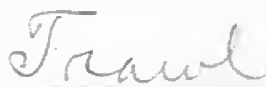

Current number of observation,

Date,

Locality,

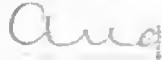

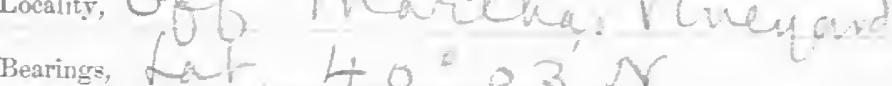

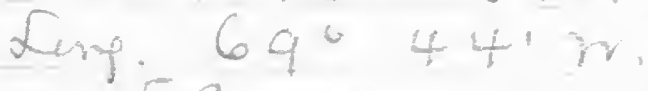

Time of dar, 5,30 ; df fidet

State of sky, $f, c$,

Temperature of air, 7 .

"surface of water, $\neq \sqrt{ }$,

. at depth of 10 fathons, 62 .

"s of bottom, 4

Depth, in fathoms, $\quad 62=65 /$ sum,

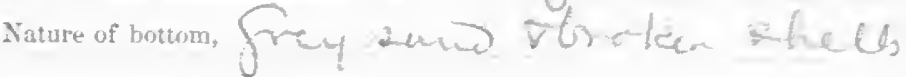

Direction of surface current,

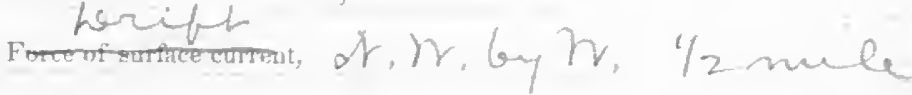

Direction of bottom current,

Force of bottom current,

Name of ressel,

To what service attached,

Name and rank of commandiug ufficor,

Name and position of ohserver, 
1092.

REMARKS.

Archancí tecorac.

Pennalucá a euceala

Qxcason.

Reuthagums.

Rasidas.

Laran Labes.

Tekugulé tragié 
TEMPERATURE RECORD.

Instrument used, Trave

Current number of observation,

Date, Clump.

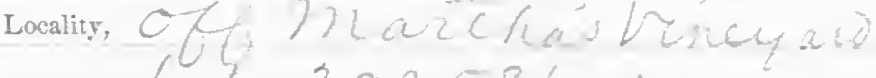

Bearings, Lat a $q^{\circ} 58^{\prime}$ N

Love, 6904

State of sky, Zn, $C$.

Temperature of air, $\quad$ t

"surface of water,

$\therefore \quad$ at depth of fathoms,

" of bottom, $/ /$

Depth, in fathoms, $\quad 194=202$.

Nature of bottom,

gravy

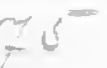

Direction of surface current,

incite

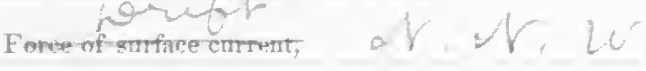

n

Direction of bottom current,

Force of bottom current,

Name of vessel,

To what service: attached,

Name and rank of commanding officer,

Name and position of observer, 
REMARKS. 


\section{TEMPERATURE RECORD.}

Instrument used, $\quad$ I $R$ a . . . $C$

Current number of obsertation, 1093

Date,

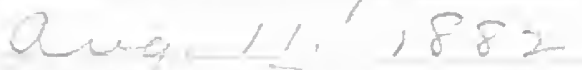

Locality,

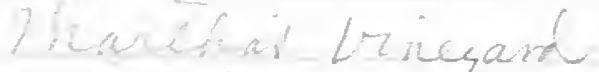

Bearings, $\alpha_{a} \neq 39 \circ 56$ 'ano" sh,

$$
\text { Sali, } 69045^{\prime}-1 y
$$

Time of day, of, 3,5 , a

State of sky, $\hat{b}_{i} \in$

Temperature of air, 82

“. surface of water:

$\therefore \quad$ of bottom, $\quad$ \% ,

1)epth, in fathoms,

Nature of bottom,

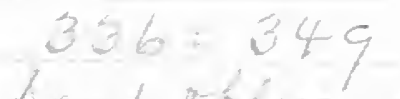

Direction of surface current,

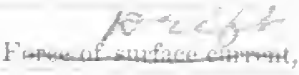

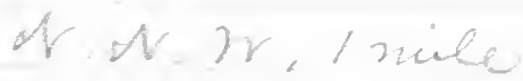

Direction of bontom current,

Force of hotiom current.

Name of ressel,

To what service attached,

Name and rank of commanding officer,

Yame and position of observer, 
REMARKS. 


\section{TEMPERATURE RECORD.}

Instrument used,

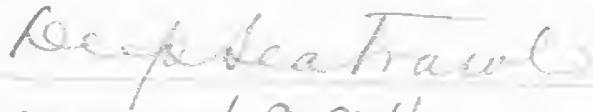

Carrent number of ubsersation,

Date,

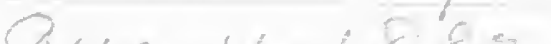

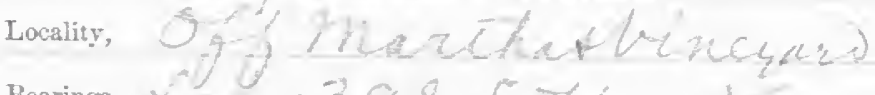

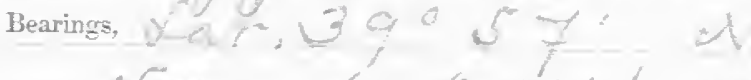

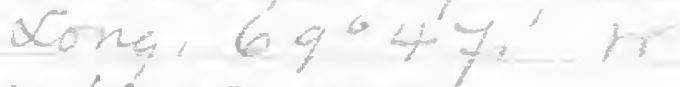

Time of day, $/ 0,<0 ;$ iftide; s

State of sky,

Temperature of air, $S</$

. surface of water,

.. at depth of fatloms.

"of bottom, $\& \&$

Depth, in fathoms, \& $\subseteq \%$,

Nature of bottom,

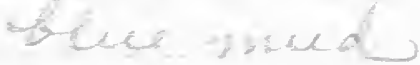

Ilirection of enrface currtut,

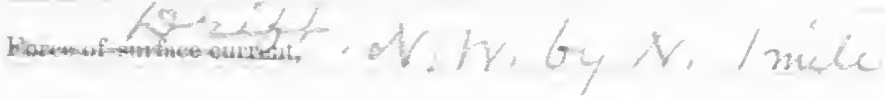

Direction of bothom current.

Forec of bottom currest,

Name of ressel,

To what service attached,

Name and rank of commanding stficer,

Name and position of observer, 
REMARKS. 


\section{TEMPERATURE RECORD.}

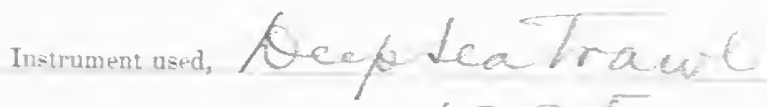
Current number of ohiservation, $\quad \mathrm{OSO}$

Date,

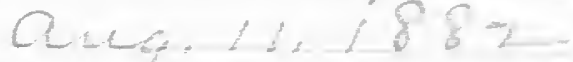

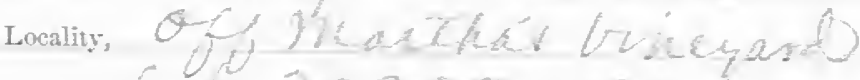

Bearings,

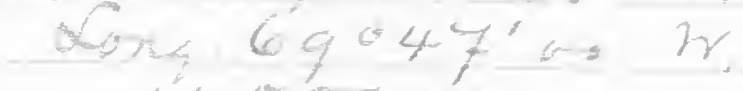

Time of day, $/$, , 6 , of tifte,

State of sky, $t=$

Temperature of air, 12

$\therefore \quad$ surface of water, $\% 6$,

.. at depth of fatloms,

" of bottom, 40.

Deptb, in fathoms, $32 \%$

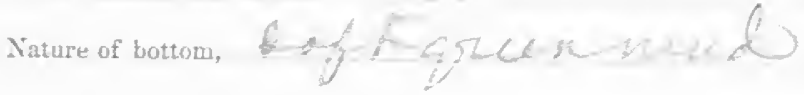

Direction of surface current,

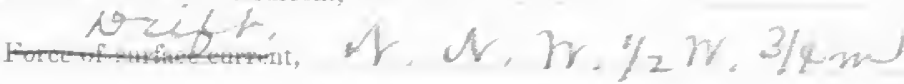

Direction of bottom current,

Force af bottom current,

Name of vessel,

To what service attached,

Name and rank of commanding officer,

Name and position of observer, 
REMARKS. 


\section{TEMPERATURE RECORD.}

Instrument used, $\sqrt{\text { TCacerl. }}$

Current number of ohserration, 1096.

Date, Ocer, 1, 1882

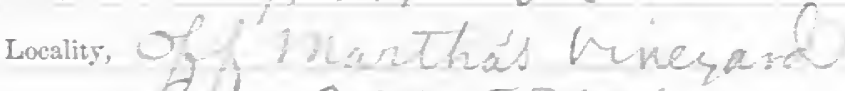

Bearings, det. 390,53 .

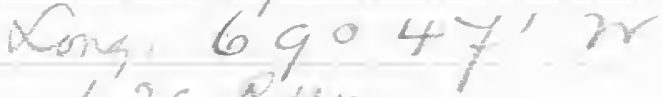

Time of das, 39 , if tidy.

State of sky, to . $c$.

T+mperature of air, 78 .

.. surface of water. 75,5

“. at depth of fathoms,

"of bottom, $4 \mathrm{C}$.

Depth, in fathoms, 3,7 ,

Nature of botton, $q$ recex rated

Direction of surface current,

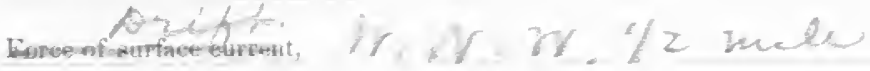

Direction of tortom current,

Force of bottom current,

Name of vessel,

To what serrice attached,

Name and rank of commandine officer,

Name and position of obserser, 
REMARKS. 


\section{TEMPERATURE RECORD.}

Instrument used,

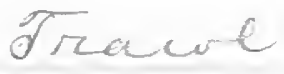

Curretit andulaer of oliservation,

Date,
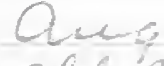

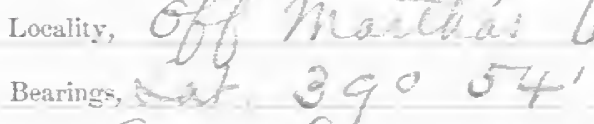

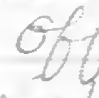

$$
\text { Fin } 1,-6,2
$$

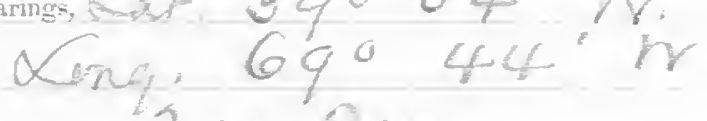

Time of day, $3, \beta O \quad$; of yide,

State of sky,

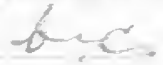

Temperature of air, $f(6)$

$\therefore \quad$ surface of water. $7 \mathcal{C}, 5$

. at depth of tinthoms,

$\therefore$ of botton, \& 5 ,

T) puth, in fathoms, 158 ,

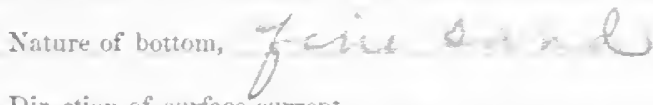

Dirtetion of surface current,

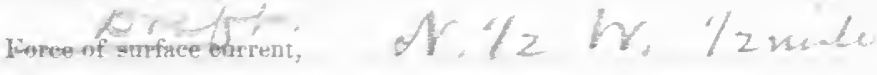

Direction of bottom current;

Force of bottom current,

Name of ressel,

To what service attached,

Name and rank of commanding officer,

Name and position of observer, 


\section{REMARKS.}




\section{TEMPERATURE RECORD.}

Insirument used,

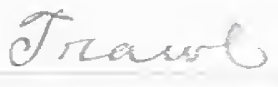

Curreat number of whervation, $/ 008$.

Date.

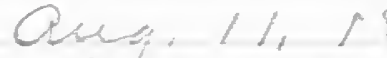

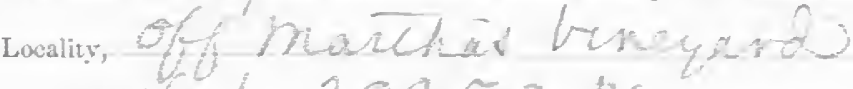

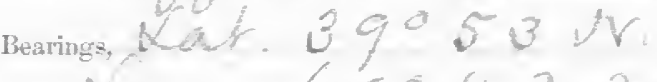

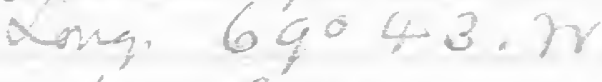

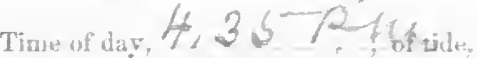

State of sky, fo.

Twmperature of air, 78 .

sulfice of water, 7 ,

at depth of tisthoms,

of imettenis, 43,5

I) + roth, in fathorim, 10.

Nature of lenturn, 7 case

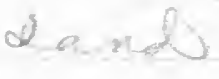

Direetion of surface cotrent,

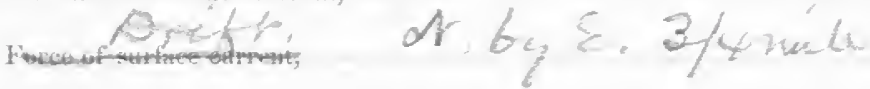

Direction of bottom carrent,

Foree of butam currang,

Nanje of vesset,

To what service attached,

Name and rank of commandiıs vflicer,

Name and position of observer, 
REMARKS. 


\section{TEMPERATURE RECORD.}

Instrument used,

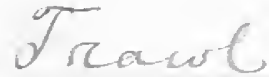

Current number of observation, $\quad 2099$

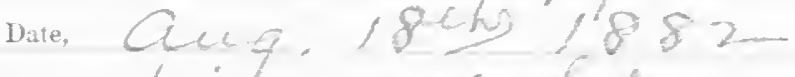

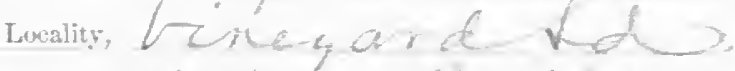

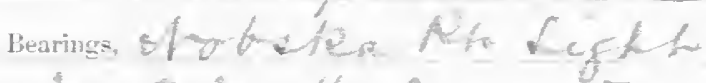

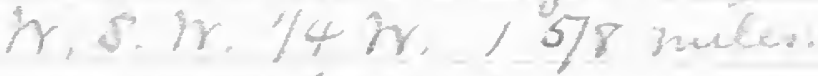

Time of day, $/, 0$ (ofting a

State of sky, $\&$.

Timptrature of air: $\frac{7}{6}$,

surface of water, $f$

“. at depth of fisthoms,

". of bottom, $\frac{1}{6} / 5$

D+pth, in fathoms, 6 ,

Nature of bottom,

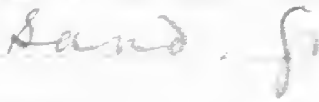

Direction of surface current,

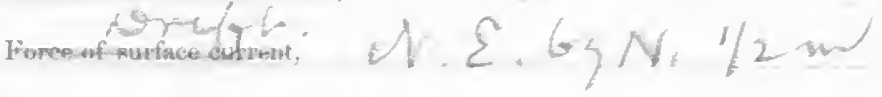

Direction of bottom current,

Force of bottom current,

Name of ressel,

To what service attacher,

Name and rank of commanding officer,

Name and position of observer, 
REMARKS. 


\section{TEMPERATURE RECORD.}

Iustrument used,

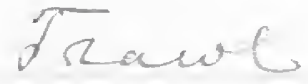

Current number of ubserration, $1 / 0$

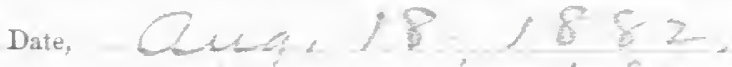

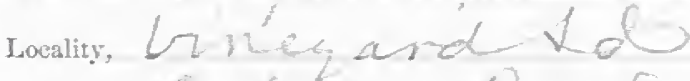

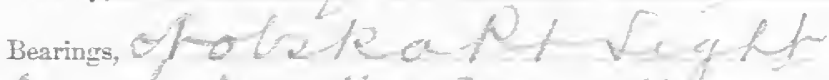

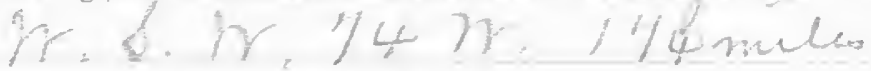

Time of day, $t /, 47$ C, of tide,

State of sky, to c.

Temperature of air, $7 \frac{1}{7}$.

- - surface of water, of 2 ,

at depth of fations,

$\therefore$ of bottum, $\quad$ of $/ w^{-}$

Depth, in fathoms.

Nature of - bottom,

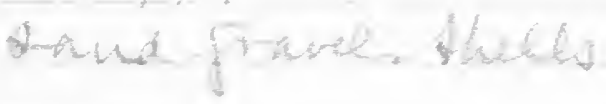

I)irection of Eurfares cHTPrit,

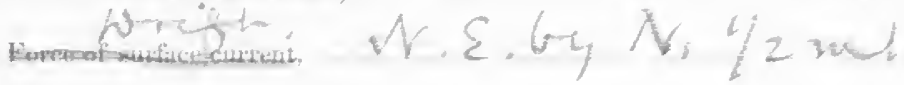

Dimetion of buttom currest,

Force of botton current,

X. ane of vessel,

T's what servicu st tactorl.

Nane athel rask of conmanding stiker,

Nane and preition of olserver, 
REMARKS. 


\section{TEMPERATURE RECORD.}

Instrument used, $9 \sqrt{r}$ acet

Current number of obserration, $/ / 0 /$.

Date, $Q, F, 8,82$

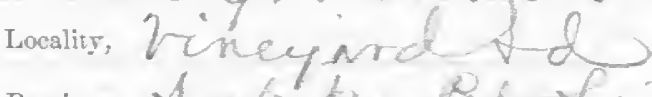

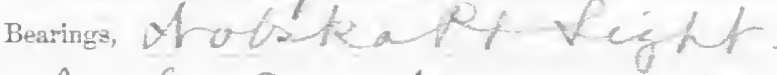

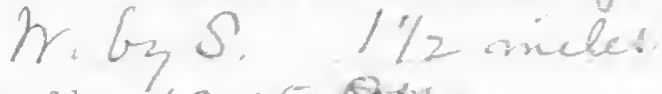

Time of day, $/ 2,15$ fothe,

State of sky,

Temperature of air, 78 .

" surface of water, 2 .

*. at depth of tithomis,

of oottom,

Deptly, in fathoms, $\mathcal{S}$,

Nature of bottom,

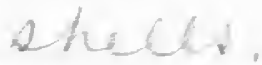

Direction of surface current,

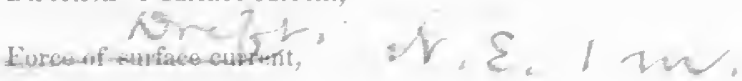

Direction of buttom current.

Foree of butiom current,

Name of ressel,

To what serrice attak leed.

Name and rank of commandiny witicer,

Name ame position of obatrerer, 
REMARKS. 


\section{TEMPERATURE RECORD.}

Instrument used,

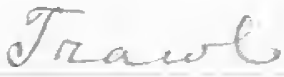

Current number of ousersation, $/ / 02$

Date, $\operatorname{lnc} q, P, 18 \mathrm{f} 2$

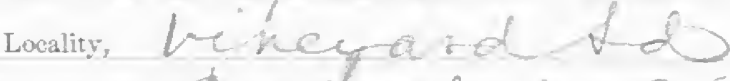

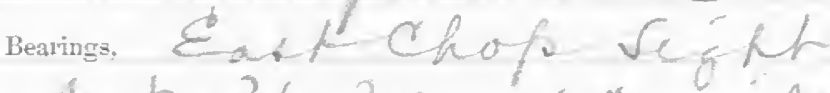

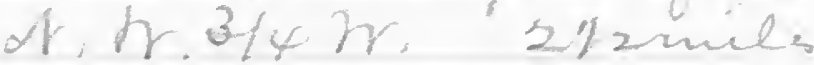

Time of day, $t, 1-0$, ortide,

State of sk, to

Temperature of air, 43 .

i. surface of water, $f$

. at depth of fathoms,

" of bottom, 609 .

Depth, in fathoms, 5 ,

Nature of bottom,

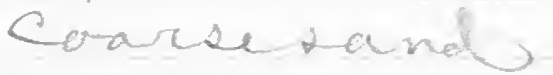

Direction of surface current,

Ewrce af aldace curtunt, Ebys.1/2m

Direction of bottom currelit,

Force of bottom current,

Name of ressel,

To what service attached,

Nane and rank of commanding ufficer,

Name and position of ohaerver, 
REMARKS. 


\section{TEMPERATURE RECORD.}

Instrument used,

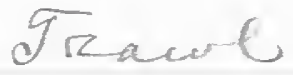

Current number of observation, _ $1 / 03$.

Date, Quef $88 \mathrm{f} 2$

Locality, $\sqrt{2} \mathrm{e}^{2} \mathrm{y}-\mathrm{w} d \mathrm{~d}-\mathrm{d}$

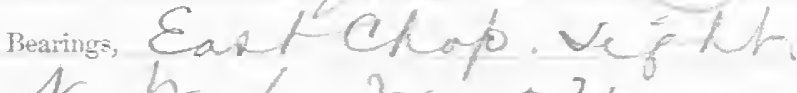

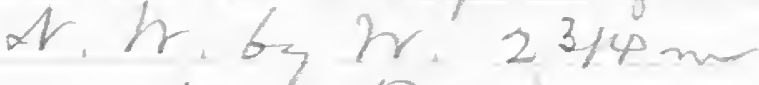

Time of iay, $f, 42$, of tidus

State of $\mathrm{ky}, \quad 0,<$

T+mplerature of air, 70 .

$\therefore$ surface of water: 70 .

- at depth of fathoms,

$\therefore$ of bottom, 69.

I)

Nature of bottom,

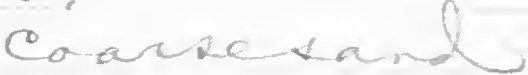

Direction of surface eurrent,

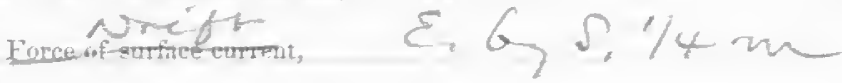

Direction of bottom eurrent,

Force of lesttom current,

Name of ressel,

To what service attached,

Name and rank of commanding ufficer,

Name and position of obserser, 
REMARKS. 


\section{TEMPERATURE RECORD.}

Instrument used,

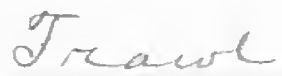

Current number of observation, $/ 10 L$

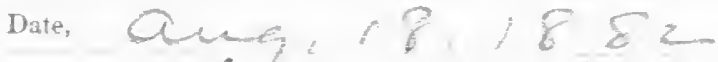

Locality,

Bearings,

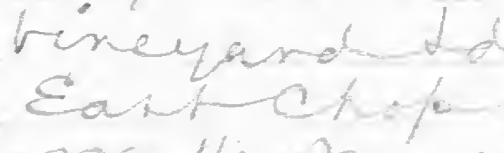

)

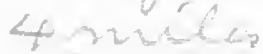

Time of day, 2,12 poftinte

State of sky,

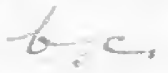

Templerature of air,

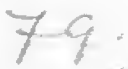

" surface of water,

as depth of

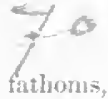

" of bottom, $6 \mathrm{C}$

Depth, in fathoms, $\quad 8 \%$

Nature of bottom,

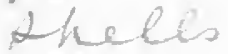

Direction of surface current,

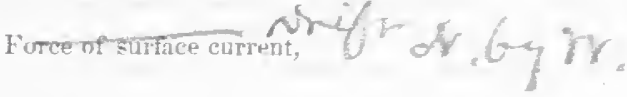

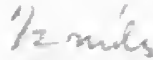

Iirection of bottum current.

Eorce of boftom currezit,

Name of ressel,

To what service attached.

Name and rank of commanding officer,

Name and position of obaerser, 
REMARKS. 


\section{TEMPERATURE RECORD.}

Instrument nsed,

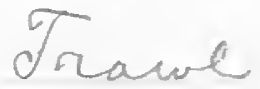

Current number of observation, $/ 105$

Date, $\mathrm{Pu}, 18,1 \mathrm{P}_{2}$

Locality, ocherper of fd.

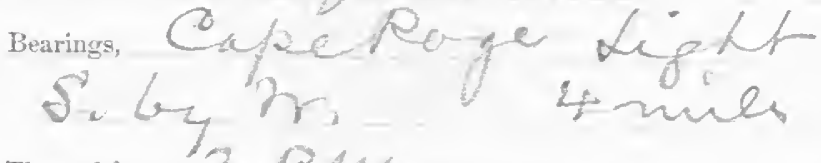

Time of day, 3 2/4 the tide,

State of sky,

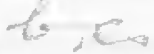

Temperature of air,

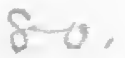

"surface of water, $\quad$ f $z$

". at depth of fathons,

"s of bottom, 7 ,

Depth, in fathoms, $<C$

Nature of bottom,

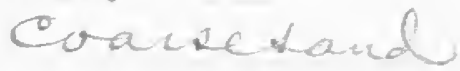

Direction of surface current

Foree of surfoce cim ront,

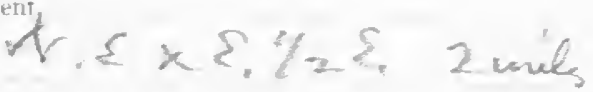

Direction of เหxtom current,

Force of bottom current,

Name of ressel,

To what serrice attached,

Name and rank of commanding officer,

Name and position of olserser, 
1106

REMARKS.

$\begin{array}{ll}1,0227 & 72 \\ 1,0027 & 72\end{array}$ 


\section{TEMPERATURE RECORD.}

Instrument uzed,

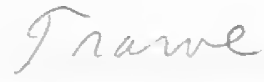

Current number of ohserration,

1106

Date, $f_{i} \therefore 18$

Locality,

1882

Bearings:

312
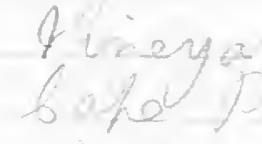

Time of day, $\beta .33^{-}$; of tide.

State of sky,

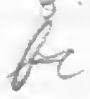

Temperature of air, 80

“ surface of water, $79 / 2$
$\therefore \quad$ at depth of tatlions,
$\therefore \quad$ of bottom. 772

Depth, in fathoms, $\boldsymbol{S}^{-}$

Nature of hottom, o a of of aluefine

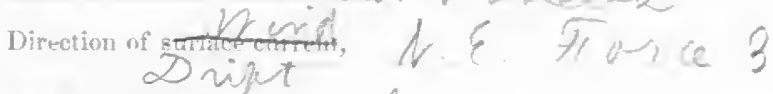

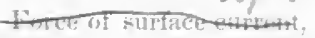

Direction of bottom current,

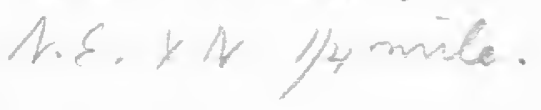

Force of bottom eurrent,

Name of stssel,

To what service attacherl,

Name and rank of cummanding officer,

Name and position of olseerser, 
1107

REMARKS.

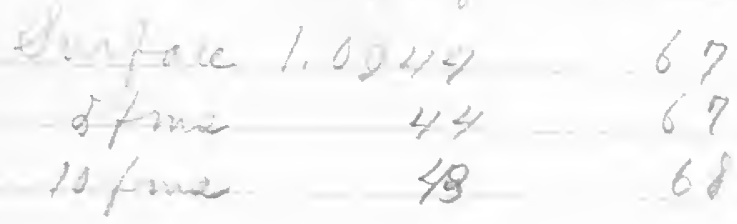

Iname toe 6.12 down 6 25

baving in 6.46 wh 6.54 220 frus. met

thata Haul 


\section{TEMPERATURE RECORD.}

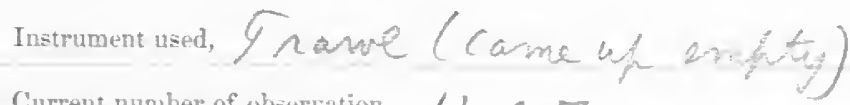

Current number of observation, 1107

Date, freg 221882

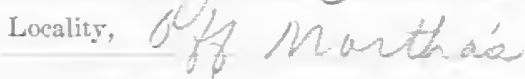

Bearings,

$$
\begin{aligned}
& \text { Dat } 4 b^{\circ}-02^{\prime} n \\
& \text { Lang. } 70^{\circ}-35^{\circ} \mathrm{n}
\end{aligned}
$$

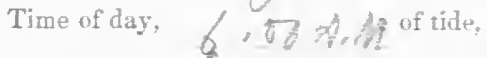

State of sky,

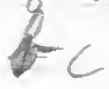

Temperature of air, $69 \%$

" surface of water. $7 /$

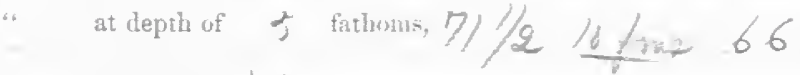

"of bottom, 48

Depth, in fathoms, $/ 16$

Nature of bottom, qhey man of

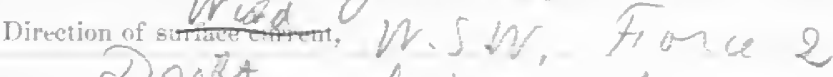
Forve of 1. In 1

Direction of bottom current,

Force of bottom current,

Name of ressel,

To what serrice attached,

Name and rark of commanding officer',

Name and position of olserver, 


\section{TEMPERATURE RECORD.}

Instrument used, $\quad$ a une

Current number of whiervation, / 8 f

Diste, Aug, 02 if o 2

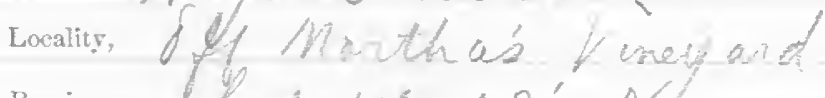

Bearings. $2 a_{1}+40^{\circ}-02$

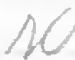

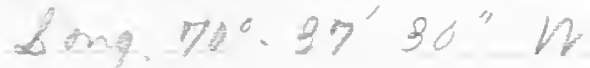

Time of das, $6, \pi\}$; of tide.

State of sky,

THmperature of air, $69 \%$

" surface of water,

a at depth of fathoms,

" of bottom, $4 / 8$

Depth, in fathoms, $\quad 401$

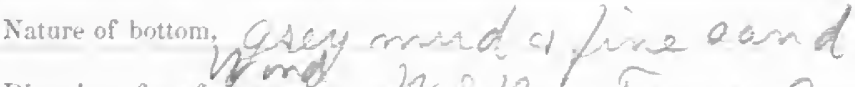

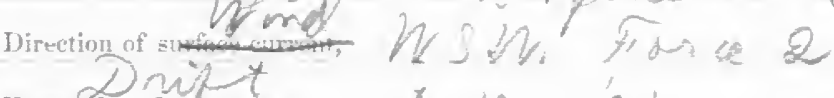

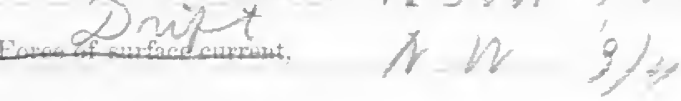

Direction of bottsm current,

Force of bottom current,

Name of ressel,

To what service attached,

Name and rank of commanding officer,

Name and position of ohserver, 
1109

REMARKS. G writ:

Surfac /.0049

66

5 tima. $\quad 2,9$

$6 \%$

$10+2 m_{2}$

44

68

Trame over 8.00 drom 8.10 hoaving in 8.45 up 8.50

250 tind ant 


\section{TEMPERATURE RECORD.}

Instrument used, Yhane

Current number of olservation, /109

Dite, furg. 22 /8 o

Locality, $O$

Bearings,

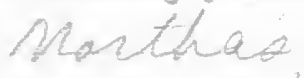

4 inely a 24

$$
\text { and } 70^{\circ}-30^{\prime} \mathrm{W}
$$

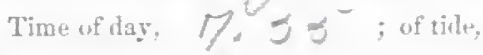

State of sky, $1 / \mathrm{C}$

T'+munerature of air, $D / 8$

a surface of water; $7 /$

. at deptb of fatlums,

$\therefore \quad$ of bottom, 29

Depth, in fathoms, $\delta 9$

Nature of bottom, I $2 a y, 2 a n$

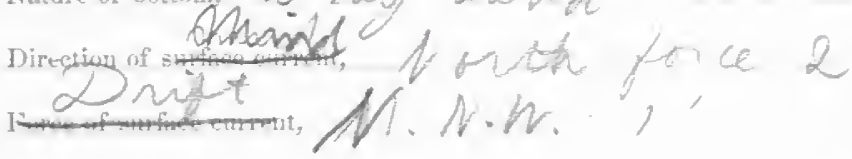

Direction of boltom eurrent,

Foree of botwm current,

Name of ressel,

To what service attached,

Name and rank of commanding wffier,

Name and position of ohserver, 
1110

REMARKS.

PLE. Y in

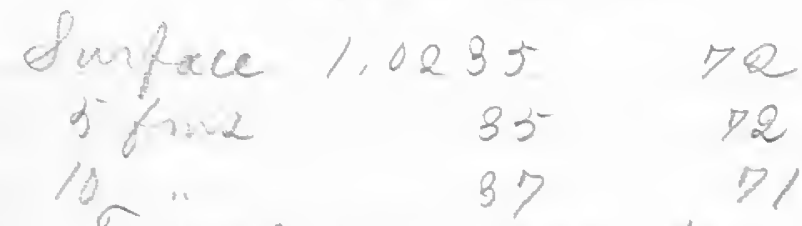

I carne over 9.25 down 9.85

Laving in $10.65^{\circ}$ wa 18.18 


\section{TEMPERATURE RECORD.}

Instrument used, $\quad(n$ are

Current number of observation, $/ 1 / 0$

Date, fueq. oृ if \&

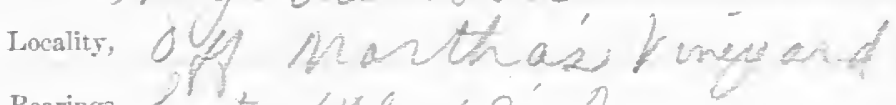

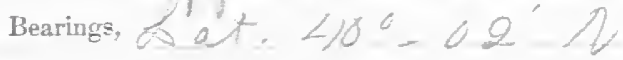

$$
3 \text { ma. } 170^{\circ}-33^{\circ} 27
$$

Time of day,

State of sky, fc

Temperature of air, $\quad 7 \$^{-}$

" surface of water, 72

i. at depth of fathoms,

" of bottom, 47

Depth, in fathoms, $\quad / 2$

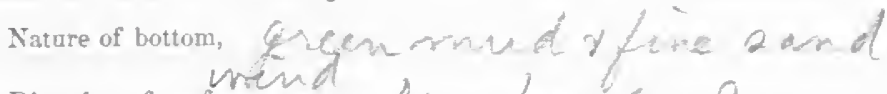

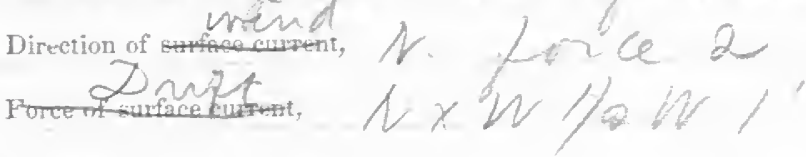

Direction of bottom current,

Force of buttom current,

Name of ressel,

To what service attached,

Name and rank of commanding officer,

Name and position of olserver, 
1111

Sher. Grian

Surface 1.0299 7!

5 time

tothe $40 \quad 72$

40

70 haming in 11.30 a/e 11.40 got timid rit. 
TEMPERATURE RECORD.

Instrument used, Deck dea Yaw Current number of observation, ///)

Date, Ling. $2218 \div 2$

Locality,

Bearings,

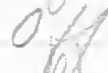

r

mast 21 bot 218.4199" "2) Ban $76^{\circ}-93^{\circ}$ in

Time of day, $18.43^{-}$; of tide,

State of sky, $f$

Temperature of air, 7

" surface of water, $792,1 \%$ \% $484<2$ " of bottom, 43

Depth, in fathoms, 224

Nature of bottom, tine $Q$ and

Direction of

NoE.

$6.1 / 2 \%$

2

sup r

Direction of bottom current,

N.

M.

Force of bottom current,

Name of russel,

To what service attached,

Name and rank of commanding officer,

Name and position of observer, 
1112

REMARKS.

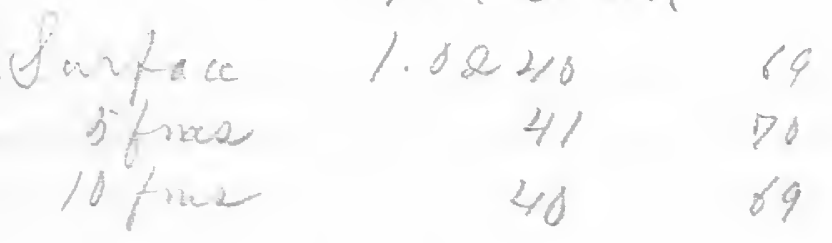

Thant mee 12.55 dumn 1.85 baning in, $81 \mathrm{at} 1.43^{\circ}$ 


\section{TEMPERATURE RECORD.}

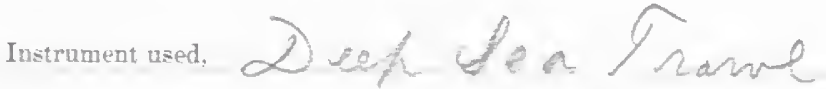

Current number of ohserration, $1 / 12$

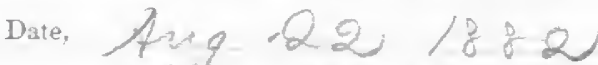

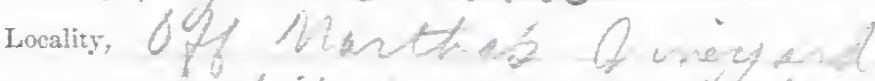

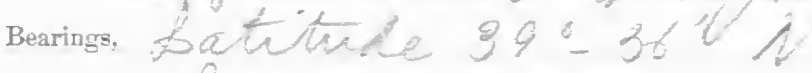

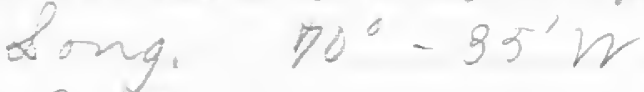

Time of da!, 12,49 ; of tide,

state of sky, $C$.

Temperature of air, 70

* surface of water, 172

. at depth of 5 fathoms, 72 toinz 6

" of bottom, 43

Depth, in fathoms, \& $4 \sigma^{-}$

Nature of botom, green maend $y$ and

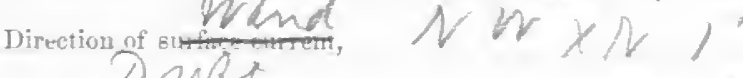

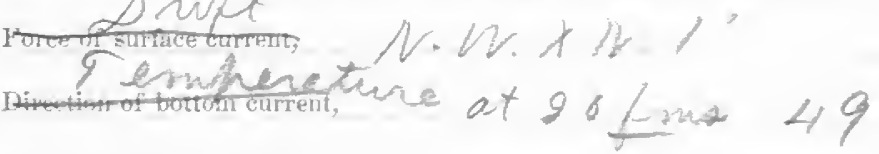

Force of bottom current,

Name of ressel,

To what service attached,

Name aud rank of commanding uffiest,

Yame and proition of observer, 
1113

REMARKS.

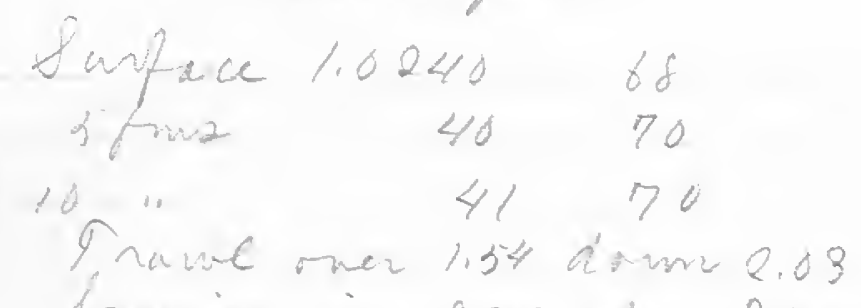

hearing in 2.25 th 2.40

395 trow. owe 


\section{TEMPERATURE RECORD.}

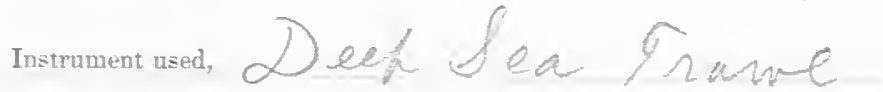

Current number of observation, $1 / 18$

Date, freg, Q⿱ 2808

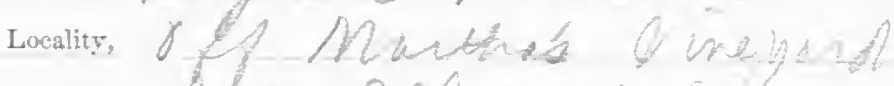

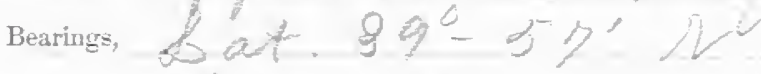

$$
\text { oring. } 7 y^{\circ}-9 y^{\circ}
$$

Time of day, $\quad /, 4 g^{-}$; of tide,

State of sky, $f_{C}$

Temperature of air, $7 \sigma^{-}$

" surface of water, 72

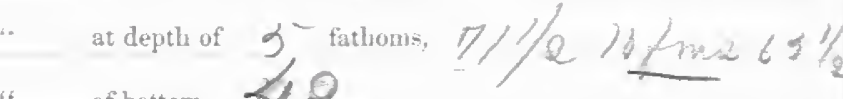

" of bottom, $>0$

Deptb, in fathoms, $/ 42$

Nature of bottom, quche max
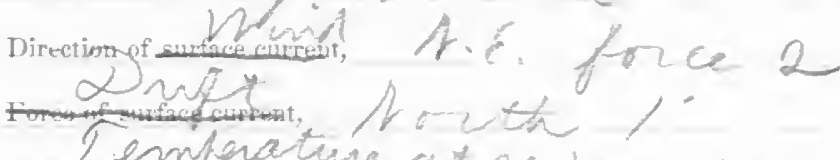

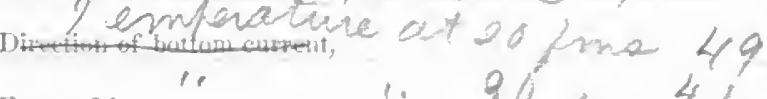

Force of botton current,

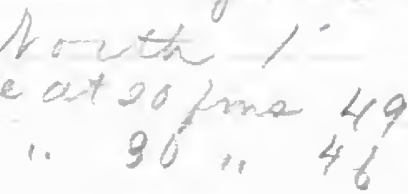

Name of ressel,

To what service attached,

Name and rank of commanding officer,

Name and position of ohserver, 
1114

REMARKS.

Frime over 2.48 dowan $2.35-$ hoaving in 9.16 wh 828 
TEMPERATURE RECORD.

Instrument used,

Duh dea Frame

Current number of observation, $1 / 14$

Date, $\operatorname{ling}, 2218 \div 2$

Locality, off Narthás Ainewant?

Bearings, is attu de $995-68^{\circ} \%$

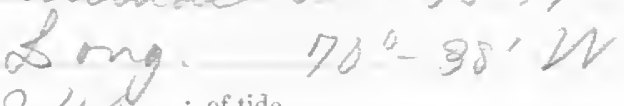

Time of day, $2,4 \mathrm{O}$; of tide,

state of sky, $\mathrm{C}$

Temperature of air, $\quad \geqslant 4$

* surface of water, 72

" at depth of 5 fathrnis, $7 / 1 / 216 / m^{2} 6 \%$ -

" of butter, 43

Depth, in fathoms,

Nature of bottom, green mat

Direction of mincemperm, N.E. farce 2

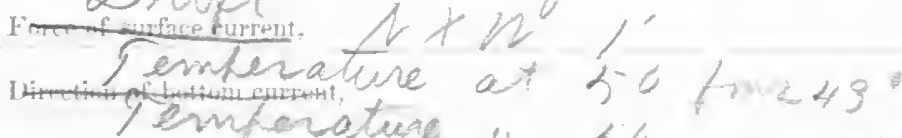

Force of bottom current,

30

Name of vessel,

To what service attarherl.

Name and rank of commanding officers,

Name and position of observer,

- fathom Ttenpranelar

$\times \operatorname{NOg}$ H

47998 
1115

REMARKS.

Drodge over $3.33^{\circ}$ dom 3.44 hearing hi 4.11 Wh 4.20 279 fma tht Hofiah. 


\section{TEMPERATURE RECORD.}

Instrument used,

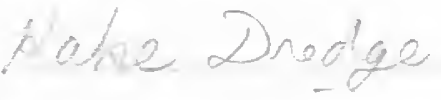

Current number of observation, / / 3

Date,

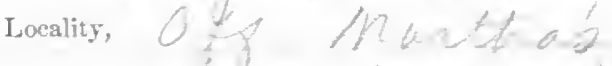

$$
\therefore \therefore 9 \cdot 28
$$

$12 \div D$

Bearings, do ata $3 a^{\circ}-59$ j

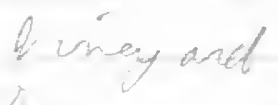

$$
\text { Brig. } 7:-4)^{\prime} 12
$$

Time of day, $5 g^{2} \delta$ Patiof tide,

Siate of $\$ k y$,

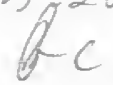

Temperature of air, $73^{\circ}$

$$
\begin{aligned}
& \text { surface of water, } 72 / 2 \\
& \therefore \quad \text { at depth of } 5 \text { fathoms, } 72 \text { tr. } 270 \\
& \therefore \text { of botton, } 43^{-}
\end{aligned}
$$

I) puth, in fathoms, $\quad 1<16$

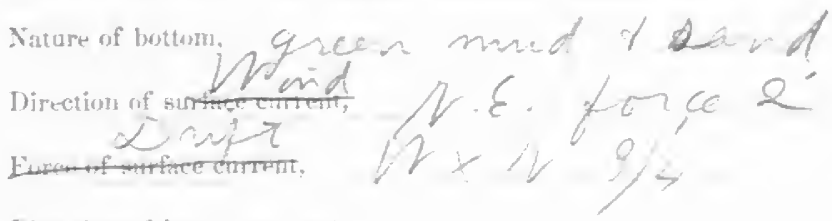

Diretion of botton current,

Foree of buttom currest,

Name of ressel,

To what service attachorl,

Nime and rank of cermmanding otficer,

Name and position of otserver, 
1116

REMARKS.

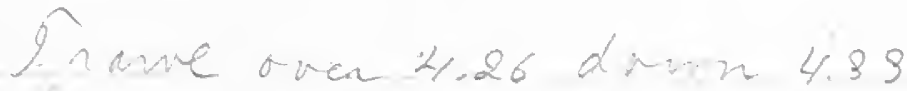
- Lawing in 4.53. wh son Q 0 finz. ant

tot s.oo got awurding in 146 f mo. 


\section{TEMPERATURE RECORD.}

Instrument used,

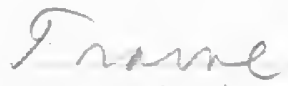

Current number of observation, $/ 1 / 6$

Dute, $f+9,2=1832$,

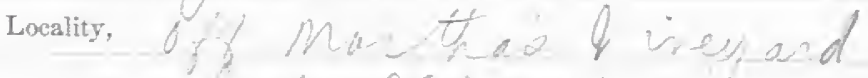

Bearings,

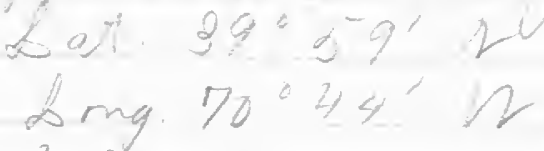

Time of das. 4.20 ; of tide,

Siate of sky, fo. $\dot{C}$

Temperature of air, $\quad 77$

surface of water, i> 2

at deptl of $3^{-}$fathmns. $72 / 1 / m=6 \%$

of botton, $4 / 6$

Dejuth, in fathoms, 14

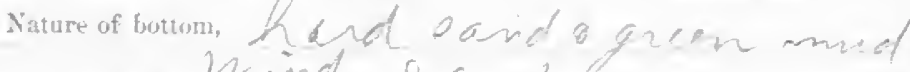

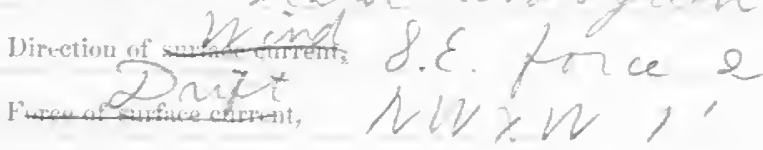

Direction of tostum current.

Furce of bottems cturent,

Xame of ressel,

To what service attacherl.

Name and rank of commanling ofitorer,

Name and position of obserrer. 
$/ / / 7$ REMARKS.

Frame one 5.97 atman 5.41 mowing in 6.01 uh 6.12 


\section{TEMPERATURE RECORD.}

Instrument used, $S$ nanpl

Current number of observation,

Date,

$\operatorname{tin} 22 / 8: 2$

Locality,

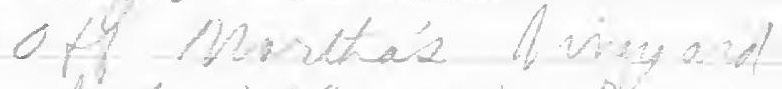

Bearinge, $\quad$ a 4 : $\angle Z^{\circ}-O 2^{\prime}$

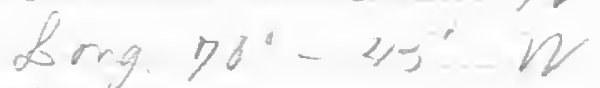

Time of day, 3.90 ; of tide.

state of sky, \&C

Templerature of air, 78
" surface of water, $D Q$

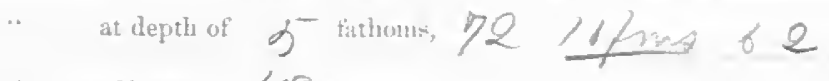
" of bottom, $4 \mathrm{f}$

Depth, in fathoms, 89

Nature of botom,

Direction of butum carrent.

Force of bottom current,

Nanue of ressel,

To what En+rico attaclied?

Nant and rank of esmmauding oflicere,

Name and position of observer, 
$1 / i_{8}$

REMARKS.

Trame wer 6.25 dorn 6.98 haduing wi $6.33^{-}$wh 6.40 240 trma. ant 
TEMPERATURE RECORD.

Instrument used, Ir awe Current number of operation, $/ / 8$ Date, flung 20 Locality, Bearings, tAng 22,$8 ; 2$ Long. $70^{\circ}-45^{\circ}$ in Time of day, 620 - 6 blot tide. state of sky, of $c$ Temperature of air, $7<$

"... surface of water, 72

.. at depth of fathoms,

"6 of bottom,

Depth, in fathoms, 7

Nature of bottom, fun e 2 \&and

Direction of

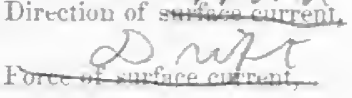

s

$$
\text { force a. }
$$

H.A.M

Direction of bottom current,

Force of bottom current,

Name of vessel,

To what service attached,

Name and rank of commanding officer,

Name and position of observer, 
1119

REMARKS.

Iname oner 6.97 dram-6.41 hewwing in 7.12 u/ 7.02

$2 / 5$ tmo. out

At 5.22 got evanding in 506 ón

Laugetreplumse deceneosrata.

Acchaster Amenicand 
TEMPERATURE RECORD.

Instrument used,<smiles>CCCCCCCCCCCCCCCCCC</smiles>

Current number of observation, 1) /9

Date, Anger 1882

Locality, of if autuchet

Bearings, bat $40^{\circ} 68^{\prime} \mathrm{D}$

$-\infty \sin -6 z:-45$

Time of day, $6 ; 0$; $9 f^{\text {idle }}$

state of sky, $\quad f \quad C$

Temperature of air, 68

". surface of water, 65

". at depth of 5 fathoms: $65^{-}$

" of bottom, 48

Depth, in fathoms, 97

Nature of bottom, o and i th prem shall

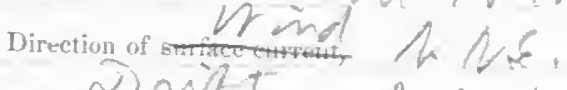

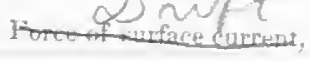

2. $\varepsilon$.

Direction of bottom current,

Force of bottom current,

Name of vessel,

To what service attached,

Name and rank of commanding officer,

Name and position of observer, 
1120

REMARKS.

Thame over 7.59 dom 8.03 having in 8.90 wh 8.45

Lotof Artiophoton Namanctici. thot Refore latke on as. Solium thaindi fiay. Alpaturiea ducemertidia depho-dteimptomi 及uecunus cusctakum Syph pubacent

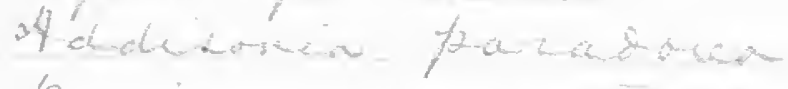
Lowis complanala tyalinaccia azlifey

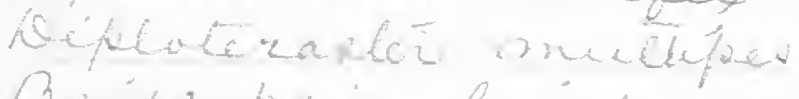
Bickopic byigacia Porania pherucera Archarie of gutrizu 
TEMPERATURE RECORD.

Instrument used, Trave

Current number of observation, $1 / 20$

Date. Sting. 26.1882

Locality, off Namtar closet

Bearings, Dat $40^{\circ}-03^{\prime} 1$

$$
\text { bong. } 68^{\circ}-40^{\circ} \text { in }
$$

Time of day, $\quad 74<4$, fin tide,

state of sky, $\mathbb{C} C$

Temperature of air, 69

" surface of water, $63^{-}$

$\therefore$ at depth of $b^{-}$fathoms: $65^{-}, 0+10$ j 6 " of bottom, $49 / 2$

Depth, in fathoms, $/ 44$

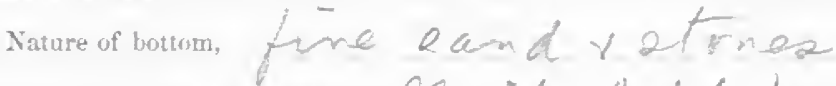

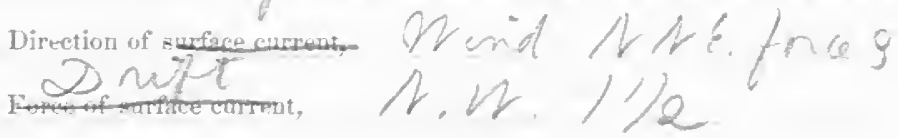

Direction of bottom current,

Force of bottom current,

Name of vessel,

To what service attached,

Name and rank of commanding officer,

Name and position of observer, 
1121

REMARKS.

Iname nee 9.18 dom 9.26 having in $9.48 \mathrm{wh} 10.05$ S.5. finc. out.

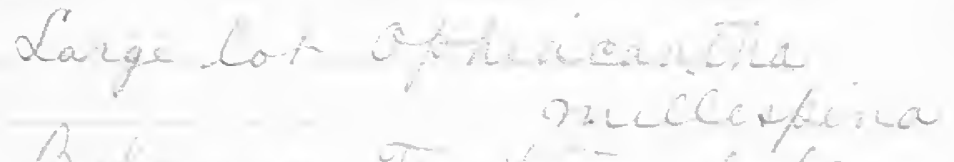

Dolacera Tucedià CaC,

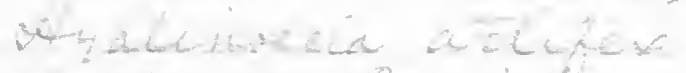

Noluim Patidie threg

Pection wílect

Lliciaria callona

Pazanuzudea kazealiò

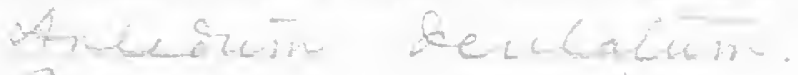

Worania frasibl. I vere

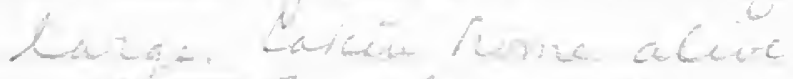

talnili Earlli Cayb

Lophanter tweeifor
cury rare) Chis aur lawt nothaks in Chis cefuir before 


\section{TEMPERATURE RECORD.}

Instrument used, Th arre

Current number of ubserration, $1 / 2 /$

Date, Ang $26 \quad 18 \pi 2$

Loeality,

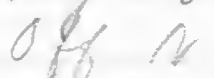

Bearings,

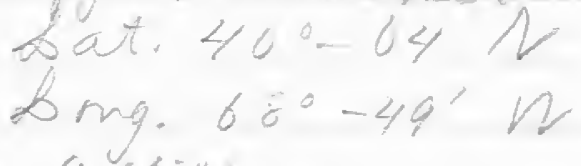

Time of day, 9.05 thlis of tide,

State of sky, $f C$

Thmperature of air, 65

" surface of water, $t o$

.. at depth of 5 fatlons. $6410 /$ me 56

" of bortom, $4 / 1 / 2$

Depth, in fathoms, 294

xature of bortom, fine dir d y pasil atrines

Directigy of suthernent, A $y=$

n-12 12

ce 4

Direction of bottom current,

Furce of bxttom currest,

Name of ressel,

To what service attached,

Natne and rank of commanding wificer,

Name and position of observer, 
REMARKS. 